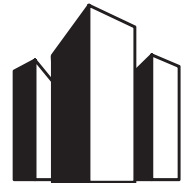

УДК 351/354; 614.846.6

doi: $10.15421 / 1520174$

\section{Державне управління системою технічного обслуговування пожежно-рятувальної техніки при передачі частини функцій до аутсорсингу}

\author{
С.В. Говорун \\ sergejgovorun@yandex.ua
}

Дніпропетровський регіональний інститут державного управління

Національної академї державного управління при Президентові Украӥни, 49044, Дніпро, вул. Гоголя, 29

У статті проаналізовано ефективність державного управління системою технічного обслуговування $\mathrm{i}$ ремонту пожежно-рятувальної техніки в Україні. Зокрема з`ясовано, що на теперішній час вона потребує негайних докорінних змін, котрі зламають механізм блокування ефективної роботи по підтриманню в належному технічному працездатному стані пожежно-рятувальної техніки. Охарактеризовано закономірності, що існують у цій системі. Оцінено вплив діяльності органів державного управління у цій сфері. Запропоновано принципово нову трирівневу багатоканальну систему технічного обслуговування і ремонту пожежно-рятувальної техніки із передачею частини функцій на третьому рівні до аутсорсингу. Доведено із позиції теорії ймовірності, що запропонована система має переваги у надійності функціонування над іншими. Запропоновано прийняти трирівневу багатоканальну систему як основну для реформування системи технічного обслуговування і ремонту пожежно-рятувальної техніки.

Ключові слова: пожежна безпека; трирівнева багатоканальна система; теорія ймовірності; ефективність; аналіз

\title{
Public administration of the state system of maintenance of firetrucks during the transfer of functions to the outsourcing
}

\author{
S.V. Govorun \\ sergejgovorun@yandex.ua \\ Dnipropetrovsk regional institute of public administration of National academy \\ for public administration under the President of Ukraine \\ 29, Hoholya St., Dnipro, 49044, Ukraine
}

The article deals with the interaction models of subjects of formation and realization of youth policy: civil society institutions and public authorities. The author argues, that the interaction of subjects, based on the principles of equality, information openness of subjects activities for each other, acceptance by the sides of equal responsibility for the results of joint activity can effectively solve social contradictions, determine optimal solutions to actual problems, integrate potential, resources of subjects of social relations during formation and realization of youth policy.

Considered the typical models of social partnership and the principles of social partnership in the sphere of youth policy: subject-subject and subject-developing models (in its social-positive variants), and object-oriented or object-subject.

Emphasized that partnership necessarily involves the equitable interaction of at least two of each other, or much more of subjects, i.e. different legal entities or individuals, for whom the activity in this area is or profiled,

Цитування даної статті: Говорун С.В. Державне управління системою технічного обслуговування пожежно-рятувальної техніки при передачі частини функцій до аутсорсингу / С.В. Говорун // Аспекти публічного управління. - 2017. - Т. 5. - № 1-2(39-40). C. 26-34.

Citation of this article: Govorun, S.V., 2017. Derzhavne upravlinnya systemoyu tekhnichnoho obsluhovuvannya pozhezhno-ryatuval'noyi tekhniky pry peredachi chastyny funktsiy do aut.sorsynhu [Public administration of the state system of maintenance of firetrucks during the transfer of functions to the outsourcing]. Public administration aspects 5, 1-2(39-40), 26-34. doi: 10.15421/1520174 (in Ukrainian).

Peer-reviewed, approved and placed: 21.02.2017 
mandatory (public sector), or voluntarily (II and III sectors). Also clarify that the subject of youth policy can not act as a partner.

Substantiated differences in realization of these models in the spheres of state youth policy (SYP) and nongovernmental youth policy (NGYP).

Keywords: public administration; fire safety; a three-level multi-channel system; the system of technical maintenance and repair of firefighting and rescue techniques; probability theory; outsourcing; efficiency; analysis

\title{
Государственное управление системой технического обслуживания пожарно-спасательной техники при передаче части функций в аутсорсинг
}

\author{
С.В.Говорун \\ sergejgovorun@yandex.ua \\ Днепропетровский региональный институт государственного управления Национальной академии \\ государственного управления при Президенте Украинь,, \\ 49044, Днепр, ул. Гоголя, 29
}

\begin{abstract}
В статье проанализирована эффективность государственного управления системой технического обслуживания и ремонта пожарно-спасательной техники в Украине. В частности выяснено, что в настоящее время она нуждается в немедленных коренных изменений, которые сломают механизм блокировки эффективной работы по поддержанию в надлежащем техническом работоспособном состоянии пожарно-спасательной техники. Охарактеризованы закономерности, которые существуют в этой системе. Оценено влияние деятельности органов государственного управления в этой сфере. Предложено принципиально новую трехуровневую многоканальную систему технического обслуживания и ремонта пожарно-спасательной техники с передачей части функций на третьем уровне к аутсорсингу. Доказано с позиции теории вероятности, что предложенная система имеет преимущества в надежности функционирования над другими. Предложено принять трехуровневую многоканальную систему, как основную для реформирования системы технического обслуживания и ремонта пожарно-спасательной техники.
\end{abstract}

Ключевые слова: пожарная безопасность; трехуровневая многоканальная система; теория вероятности; эффективность; анализ

Постановка проблеми. В останні роки в Україні однією з основних проблем у сфері пожежної безпеки є висока спрацьованість парку пожежної техніки, 90\% наявної техніки фізично застаріла і потребує заміни [13], до того ж забезпечення належного рівня експлуатації та технічного обслуговування пожежних автомобілів знаходиться на дуже низькому рівні, а це у свою чергу призводить до несанкціонованого виходу іiі з ладу, у зв'язку з чим погіршується боєготовність пожежно-рятувальних підрозділів.

Аналіз причин виникнення такого стану справ показав, що стан цей зумовлений не тільки низьким рівнем забезпечення належного рівня експлуатації та технічного обслуговування пожежних автомобілів, зумовлений не тільки недостатнім фінансуванням, спрацьованістю пожежної техніки, але й прорахунками та недоліками в управлінні системою експлуатації та технічного обслуговування пожежних автомобілів; недосконалістю та застарілістю законодавчого і нормативно-правового забезпечення у даній сфері пожежної безпеки, що призвело до розбалансування системи управління станом експлуатації та технічного обслуговування пожежних автомобілів; низькою культурою експлуатації та технічного обслуговування пожежних автомобілів у системі ДСНС України.

Протягом кількох останніх десятиріч, що минули з часу розпаду СРСР, Українська держава переживає незадовільні часи як у політичному стані, так і у соціально-економічній сфері.

Відповідно до національної доповіді «Про стан техногенної та природної безпеки у 2012 році» [13, с. 16] однією із основних проблем у сфері цивільного захисту залишається із року в рік така нагальна проблема як «виснаженість і недостатність технічного оснащення сил цивільного захисту».

Проблема технічного обслуговування, ремонту та підтримання у задовільному технічному стані пожежних автомобілів постає на перше місце у забезпеченні оперативної готовності пожежно-рятувальних підрозділів.

Аналіз досліджень і публікацій. У ході 
аналізу наукової літератури ми дійшли висновку, що вирішення проблеми забезпечення національної безпеки, іiі управлінські аспекти вже тривалий час $\epsilon$ тематикою багатьох українських науковців таких як: В. А. Доманський [21], В. В. Бєгун [4], Є. П. Буравльов [8], Р. В. Климась [12], А. В. Михайлова [3], І. П. Кринична [9], О. П. Якименко [7] та ін., а також іх російських колег: I. М. Абдурагімова [1], М. М. Брушлинського [17], Ю. М. Глуховенка [5], С. А. Клепки [13]. Проте впровадження новітніх форм та методів державного регулювання системи пожежної безпеки у частині експлуатації та технічного обслуговування автомобілів в Україні на теперішній час $\epsilon$ недостатнім.

Проблеми організації та управління експлуатацією, технічним обслуговуванням та ремонту пожежної техніки розглядалися в роботом М. Д. Безбородька [14], М. М. Брушлинського [18], С. В. Соколова [19], С. А. Качанова [10], М. Г. Топольського [20], А. П. Сатіна [16], Н. М. Архіпця [22], О. І. Башинського [2] та інших авторів.

Разом $з$ тим, до цього часу методика моделювання функціонування реальних підрозділів з автопарком пожежної техніки залишається на рівні розробок $70-x, 80-x$ років XX ст. і заснована на принципі проведення планово-попереджувальних ремонтів, системи проведення централізованого середнього та капітальних ремонтів на базі укрупнених загонів технічної служби, при наявності великих матеріальних запасів запасних частин для пожежних автомобілів, достатньої кількості підготовлених фахівців 3 обслуговування пожежних автомобілів та існування великої працездатної ремонтно-технічної бази.

Сучасний стан свідчить про проблеми у цій сфері: достатньої кількості запасних частин немає, недостатня кількість досвідчених фахівців, ремонтно-технічна база частково практично непрацездатна, високий рівень спрацьованості верстатно-інструментального парку, відсутність обладнання для діагностування новітньої техніки, яка прибуває до пожежно-рятувальних підрозділів.

Недостатня наукова розробка питань створення ефективної системи технічного обслуговування і ремонту (ТО і Р) пожежних автомобілів (ПА) і визначає актуальність даної статті.

Тому, на нашу думку, необхідно більш детально зупинитися на проблемах, прогалинах та суперечностях, які виникли в системі державного управління процесами забезпечення пожежної безпеки на підприємствах, в організаціях, закладах і тих передбачуваних та непередбачуваних ризиках і загрозах, що існують у діяльності центральних виконавчих органів влади, які здійснюють державний нагляд у сфері техногенної та пожежної безпеки. У цьому зв'язку розглянемо сутність державного управління у сфері забезпечення пожежної безпеки та діючу систему запобігання виникнення пожеж та здійснимо оцінки iii ефективності, керованості, а також намітимо можливі шляхи зрушення ситуації, що склалася у більш позитивний бік.

Мета дослідження. Здійснити аналіз державного управління пожежною безпекою у частині експлуатації та технічного обслуговуванні пожежних автомобілів в цілях підвищення готовності підрозділів пожежної охорони для гарантування прийнятного рівня безпеки населення.

Виклад основного матеріалу. Пожежну безпеку можна розглядати як складову національної безпеки, яка знаходить підтвердження в тому, що пожежі як загрози є самостійними складовими значної частини можливих небезпек. Пожежі супроводжують терористичні акти, вибухи, дорожньо-транспортні пригоди, аварії на транспорті, виробничі процеси, природні небезпеки, протиправну діяльність людини тощо. 3 огляду на це, розглядати пожежну безпеку в складі державної, техногенної, екологічної чи якоїсь іншої безпеки $є$ не доцільним. Проблема пожежної безпеки як реальна, чинна складова національної безпеки не нова, але потребує насамперед коригування правового підгрунтя.

Отже, управління пожежною безпекою - цією невід'ємною частиною державної діяльності, це складова галузі державного управління. Тому принциповою особливістю системи державного управління пожежною безпекою $€$ те, що вона немовби «занурена» у «загальну» систему державного управління. Система державного управління пожежною безпекою здійснює потужний вплив на спрямованість, зміст та ефективність адміністративно-політичного, соціально-економічного та інших видів державного управління внаслідок стратегічного значення державноуправлінських рішень, які нею приймаються, 
для суспільства та держави, особливо в умовах, коли стоїть досить гостро питання щодо нейтралізації загроз життєво важливим інтересам. Це означає, що функції системи виходять, наприклад, за межі адміністративнополітичної чи соціально-економічної сфери державного управління.

3 огляду на вищевикладене, система державного управління пожежною безпекою - це сукупність взаємообумовлених, взаємодіючих органів державного управління та вищих посадових осіб держави, яка в межах чинного законодавства та із залученням наявного у розпорядженні потенціалу держави (матеріального, фінансового, інтелектуального та духовного) здійснює розробку й реалізацію владних, регулюючих, координуючих, контролюючих та нормативних державноуправлінських впливів (рішень) на об’єкти безпеки $з$ метою прогнозування, своєчасного виявлення, запобігання та нейтралізації загроз сталому розвитку вищезазначених об'єктів, передусім життєво важливим національним інтересам. Державне управління може здійснюватися у двох режимах - нормальному та надзвичайному. Це певною мірою допомагає зрозуміти суть проблемної ситуації, розвитку процесу державного управління.

Питання удосконалення державного управління пожежною безпекою у частині експлуатації та технічного обслуговування пожежних автомобілів для підвищення ступеня готовності підрозділів пожежної охорони, що забезпечує існування гарантованого прийнятного рівня безпеки населення - це питання базове, фундаментальне, тому що воно являє собою основу, підгрунтя всієї системи забезпечення пожежної безпеки, як складової цивільного захисту.

В свою чергу, система державного управління у сфері пожежної безпеки України у частині експлуатації та технічного обслуговування пожежних автомобілів складається із внутрішньої організації Державної служби України $з$ надзвичайних ситуацій, а саме - 3 Апарату ДСНС України та підпорядкованих йому структурних підрозділів.

На теперішній час експлуатація та технічне обслуговування пожежних автомобілів регламентуються внутрішнім наказом ДСНС України № 432 від 27.06.2013 року «Про затвердження Настанови 3 експлуатації тран- спортних засобів в органах та підрозділах ДСНС України» [22].

В даній Настанові визначено організаційні та функціональні схеми щодо експлуатації та технічного обслуговування пожежних автомобілів (рис. 1.1)

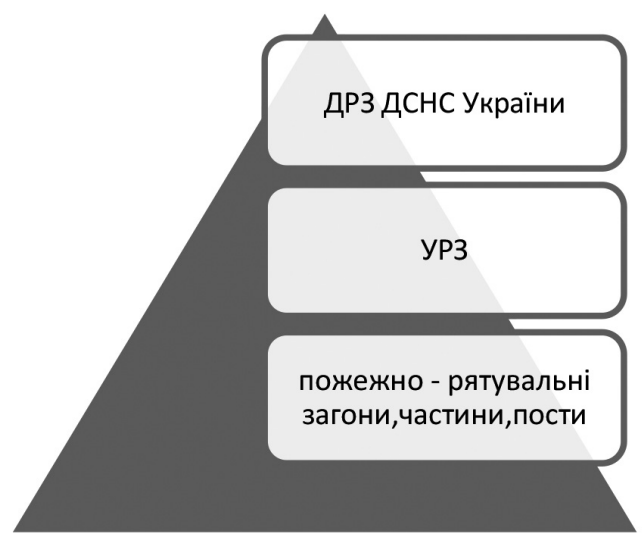

Рис. 1. Організаційна схема щодо структури управління у сфері пожежної безпеки при експлуатації та технічному обслуговуванні пожежних автомобілів. експлуатації та технічному обслуговуванні пожежних автомобілів

Згідно до пп. 1.4-1.6 Настанови, п. 1.4. Експлуатацію Т3 організовують: Департамент ресурсного забезпечення ДСНС України (далі - ДРЗ ДСНС України); управління (відділи, відділення, сектори) ресурсного (матеріальнотехнічного) забезпечення органів та підрозділів (далі - УР3); пожежно-рятувальні загони (частини, пости), аварійно-рятувальні служби та формування.

Згідно п. 1.5. загальне керівництво та відповідальність за організацію і діяльність органів та підрозділів щодо експлуатації Т3 покладено на: директора ДРЗ ДСНС України; начальників територіальних органів, керівників навчальних закладів та науково-дослідних установ ДСНС України, спеціальних регіональних центрів швидкого реагування та підрозділів безпосереднього підпорядкування Апарату ДСНС України, навчальних та науково-дослідних установ, регіональних рятувальних, спеціалізованого авіаційного та морського загонів; начальників УРЗ органів та підрозділів; начальників пожежно-рятувальних загонів (частин, постів), аварійно-рятувальних служб та формувань, директорів (начальників) установ, організа- 
цій та підприємств системи ДСНС України.

Основними завданнями органів та підрозділів, які експлуатують ТЗ, є:

- своєчасне забезпечення підрозділів пожежно-рятувальною, аварійно-рятувальною технікою та іншими ТЗ згідно із встановленими нормами, облік та перерозподіл Т3 (у межах наданих повноважень);

- утримання та розвиток матеріально-технічної бази підрозділів ДСНС України щодо експлуатації Т3;

- забезпечення готовності ТЗ до дій за призначенням;

- керівництво технічною підготовкою водіїв та інших спеціалістів, які здійснюють експлуатацію Т3;

- узагальнення досвіду роботи щодо експлуатації Т3 та розроблення пропозицій 3 iii удосконалення;

- організація належної експлуатації i ремонту Т3.

У ДСНС прийнята планово-запобіжна система ТО і Р. Суть цієї системи полягає в тому, що провадиться планування періодичності ТО і Р, а також об'єм їх робіт. Проте ТО проводиться в обов'язковому порядку, а ремонт - за потребою.

Для реалізації системи ТО і Р необхідно знати періодичність Ткм проведення робіт по TO i ремонту i трудомісткість $\mathrm{t}$, люд.-год. їх виконання.

Трудомісткість виконуваних робіт по обслуговуванню механізмів і систем визначають методом хронометрування і зазвичай задається в людино-годинах (t, люд.-год.). Для обслуговування ПА в цілому визначається термін (у добі), протягом якого воно повинно бути проведене. Зазвичай ТО включає декілька видів робіт: змащувальні, кріпильні, регулювальні. Крім того, кожен механізм і система мають свою оптимальну періодичність обслуговування [23, с. 42].

Всі системи і механізми ПА володіють певними параметрами технічних характеристик. Ці параметри не залишаються постійними впродовж терміну служби машин. Відхилення їх від номінальних (спочатку встановлених значень) характеризує зміну технічного стану систем і механізмів.

Для систем і механізмів машин встановлюють початкове значення параметрів П0, гранично допустимі Ппд і допустиме Пд. Досягши значень Пд виріб стає непрацездатним, тому встановлюють термін його обслуговування, рівним величині Ппд.

Процес нормального функціонування систем і механізмів у часі неоднаковий. Так, зміна П в більшості систем регламентується часом (або величиною пробігу ПА в кілометрах), протягом якого система нормально функціонуватиме. Первинні значення П при експлуатації ПА можуть відновлюватися. До таких систем відносяться системи подачі палива, фільтрації масла, подачі піноутворювача і тому подібне.

Параметри характеристик механізмів змінюються значно повільніше, ніж у їх систем. Як правило, досягши Ппд потрібен ремонт механізму.

Згідно 3 «Настановами 3 експлуатації транспортних засобів в органах та підрозділах ДСНС України» експлуатація та технічне обслуговування ПА проводиться шляхом здійснення технічних обслуговувань різних видів. Технічне обслуговування (надалі ТО) - комплекс операцій чи операція щодо підтримки працездатності або справності Т3 (ПА) під час експлуатації.

Під час проведення ТО Т3 (ПА) обов'язкове виконання усього обсягу робіт відповідно до виду ТО, а додаткове регулювання вузлів та систем Т3 (ПА)-на підставі висновків діагностики.

Основним методом ремонту $є$ агрегатний метод, під час якого несправні агрегати і механізми ТЗ (ПА) замінюються новими або відремонтованими, що взяті з обігового фонду. Агрегатний метод застосовується у разі, коли трудомісткість ремонтних робіт перевищує трудомісткість робіт для зняття агрегату, що вимагає ремонту, і встановлення відремонтованого або нового агрегату.

Дозволяється застосовувати індивідуальний метод ремонту, під час якого несправний агрегат знімається, ремонтується і встановлюється на той же ТЗ (ПА) при відсутності обігового фонду. Для більшості агрегатів і елементів встановлюються індивідуальні терміни експлуатації, тому доцільно робити КР і заміну окремих агрегатів поетапно.

Для проведення поточного, середнього та капітальних ремонтів, пожежний автомобіль направляється до загону технічної служби Головного управління в області.

Але ж насправді визначення термінів проведення технічного обслуговування та 
ремонту пожежних автомобілів, виходячи із ïx загального напрацювання, тобто пробігу в кілометрах, не $є$ досить коректним для внесення вихідних даних у такій системі, тому що пожежні автомобілі та інша пожежно-рятувальна техніка зазвичай працює у важких умовах надмірної задимленості, пилу, заниженої концентрації кисню в атмосферному повітрі, дії непередбачуваних дорожніх умов, таких як звалища сміття, необхідність подолання великих кутів підйому або спуску, додаткових навантажень, що діють на раму автомобіля у разі необхідності евакуації інших транспортних засобів, що зазнали аварії або потерпіли від вогню чи вибуху. Практичною відсутністю часу на прогрівання двигуна та інших систем пожежно-рятувального автомобіля у холодну пору року. Тому ми пропонуємо покласти в основу визначення системи технічного обслуговування і ремонту пожежно-рятувальної техніки в рамках марковської моделі, яка діє в рамках системи масового обслуговування. Моделювання в рамках теорії систем масового обслуговування (CMO) дозволяє визначити основні параметри, необхідні для оцінки ефективності експлуатації автопарку. Однак слід враховувати, що динаміка подібних ергодичних систем відрізняється стрибкоподібними змінами їх станів 3 наступними досить тривалими перехідними процесами. У ряді випадків коректний опис поведінки системи може бути отримано тільки при використанні нестаціонарної моделі, наприклад при дослідженні динаміки ступеня готовності до виїзду і виконання завдань з гасіння пожеж.

Приклад моделювання багаторівневої системи обслуговування та ремонту військової техніки було наведено досить та досить розкрито д.т.н., проф. Буравльовим О.I. у 2014 році в статті «Марковская модель восстановления вооружения и военной техники в новой системе технического обслуживания и ремонта» [24, с.37-52]. На основі математичних розрахунків ним було доведено, що багатоканальна система технічного обслуговування має значні переваги перед одноканальною системою, але ж у військових цілях побудова багатоканальної системи недоцільна, у зв'язку зі збільшенням громіздкості та втратою живучості. Також ним було запропоновано дворівневу систему відновлення військової техніки.
Але ж, на наш погляд, система технічного обслуговування ДСНС України діє, як правило, в умовах невійськового часу та не піддається будь-яким зовнішнім загрозам, котрі можуть вивести їі зі стійкого стану та призвести до її повного руйнування або часткової неспроможності виконувати дії за призначенням. Тому ми пропонуємо побудувати систему державного управління технічним обслуговуванням пожежно-рятувальної техніки на основі застосування трирівневої багатоканальної системи, 3 передачею частини функцій на третьому рівні системи із безпосередньо державного обслуговування в аутсорсингове технічне обслуговування. При цьому фірма, що здійснює аутсорсингове обслуговування, повинна мати змогу у будь-який час взяти на себе всі $100 \%$ функцій держави на третьому рівні даної системи. Та навпаки, і це $€$ насамперед головним, функції аутсорсингової фірми повинні бути також на 100 \% виконані державою, у разі такої потреби.

Тобто знадобиться резервування функцій і операцій, що виконуються аутсорсинговою фірмою, державою, у діючому виробничому та матеріальному технічному резерві.

Доречно вказати, що сама по собі трирівнева система має свої переваги над дворівневою, так як загальна надійність системи $\mathrm{P}_{\mathrm{s}}$, що складається із $\mathrm{n}$ елементів, $\mathrm{n}=1 \ldots 3$, що мають надійність р дорівнює:

$$
\mathrm{P}_{\mathrm{s}}=1-\left[\left(1-\mathrm{p}_{1}\right) \times\left(1-\mathrm{p}_{2}\right) \times\left(1-\mathrm{p}_{3}\right)\right]
$$$$
\text { де Ps - надійність усієї системи; }
$$

$\mathrm{p}_{1}, \mathrm{p}_{2}, \mathrm{p}_{3}$ - надійність кожного з ії елементів.

Тобто, враховуючи, що надійність (тобто ймовірність безвідмовної роботи р) - завжди менша або дорівнює одиниці $\mathrm{p} \leq 1$, то чим більше елементів системи $\mathrm{n}$, тобто кількість виразів у круглих дужках $\left(1-\mathrm{p}_{\mathrm{n}}\right)$, тим менше буде абсолютне значення у квадратних дужках. Таким чином, загальна надійність системи $\mathrm{P}_{\mathrm{s}}$ буде прагнути наблизитися до одиниці, $\mathrm{P} \rightarrow 1$, що $є$ найбажанішим станом надійності системи або однієї з їі частин.

Можливість аутсорсингової фірми у будьякий час перейняти на себе всі $100 \%$ функцій держави, і навпаки, на третьому рівні даної системи, при механізмі передачі цих функцій один до одного, підвищує рівень надійності третього рівня до:

$$
\mathrm{P}_{3}=1-\left[\left(1-\mathrm{p}_{\mathrm{z}}\right) \times\left(1-\mathrm{p}_{\mathrm{a}}\right)\right]
$$

де $\mathrm{P}_{3}-$ надійність системи 3-го рівня; 

вою;

$\mathrm{p}_{\text {д }}$ - надійність виконання функцій держа-

$\mathrm{p}_{\text {a }}$ - надійність виконання функцій аутсорсинговою фірмою.

Таким чином, надійність всієї системи буде дорівнювати:

$\mathrm{P}_{\mathrm{s}}=1-\left[\mathrm{P}_{1} \times \mathrm{P}_{2} \times \mathrm{P}_{3}\right]=1-\left[\left(1-\mathrm{p}_{1}\right) \times\right.$ $\left.\times\left(1-\mathrm{p}_{2}\right) \times\left[1-\left(1-\mathrm{p}_{\text {д }}\right) \times\left(1-\mathrm{p}_{\mathrm{a}}\right)\right]\right] \quad(3)$

де Р1, Р2, Р3 - надійність систем 1-го, 2-го та 3-го рівнів відповідно;

$\mathrm{p}_{1}, \mathrm{p}_{2},-$ надійність кожного 3 елементів відповідно систем 1-го та 2-го рівнів відповідно;

$\mathrm{p}_{\text {д }}$ - надійність виконання функцій державою у системі 3-го рівня;

$\mathrm{p}_{\mathrm{a}}$ - надійність виконання функцій аутсорсинговою фірмою у системі 3-го рівня.

Наведемо структурну схему такої трирівневої багатоканальної системи із зазначенням надійності їі рівнів та елементів (рис.2).

Треба сказати, що критерії, за якими можливе обрання тієї чи іншої аутсорсингової фірми, повинні виходити із розрахунку іiі можливості щодо здійснення певних видів робіт, тобто постачання відповідних послуг державі, наявність сертифіката відповідності стандартам якості серії ISO 9001 та ISO 9004, прозорість при наданні послуг, запобігання корупційній змові між постачальниками послуг та між постачальниками послуг та державними органами.

Висновки Таким чином, проаналізувавши стан державного управління системою технічного обслуговування та ремонту пожежно-рятувальної техніки, ми дійшли висновку, що на теперішній час вона потребує негайних докорінних змін, котрі зламають механізм блокування ефективної роботи по підтриманню в належному технічному працездатному стані пожежно-рятувальної техніки.

Ми пропонуємо принципово нову трирівневу багатоканальну систему технічного обслуговування і ремонту пожежно-рятувальної техніки із передачею частини функцій на третьому рівні до аутсорсингу. Із позиції теорії ймовірності ми довели, що дана трирівнева

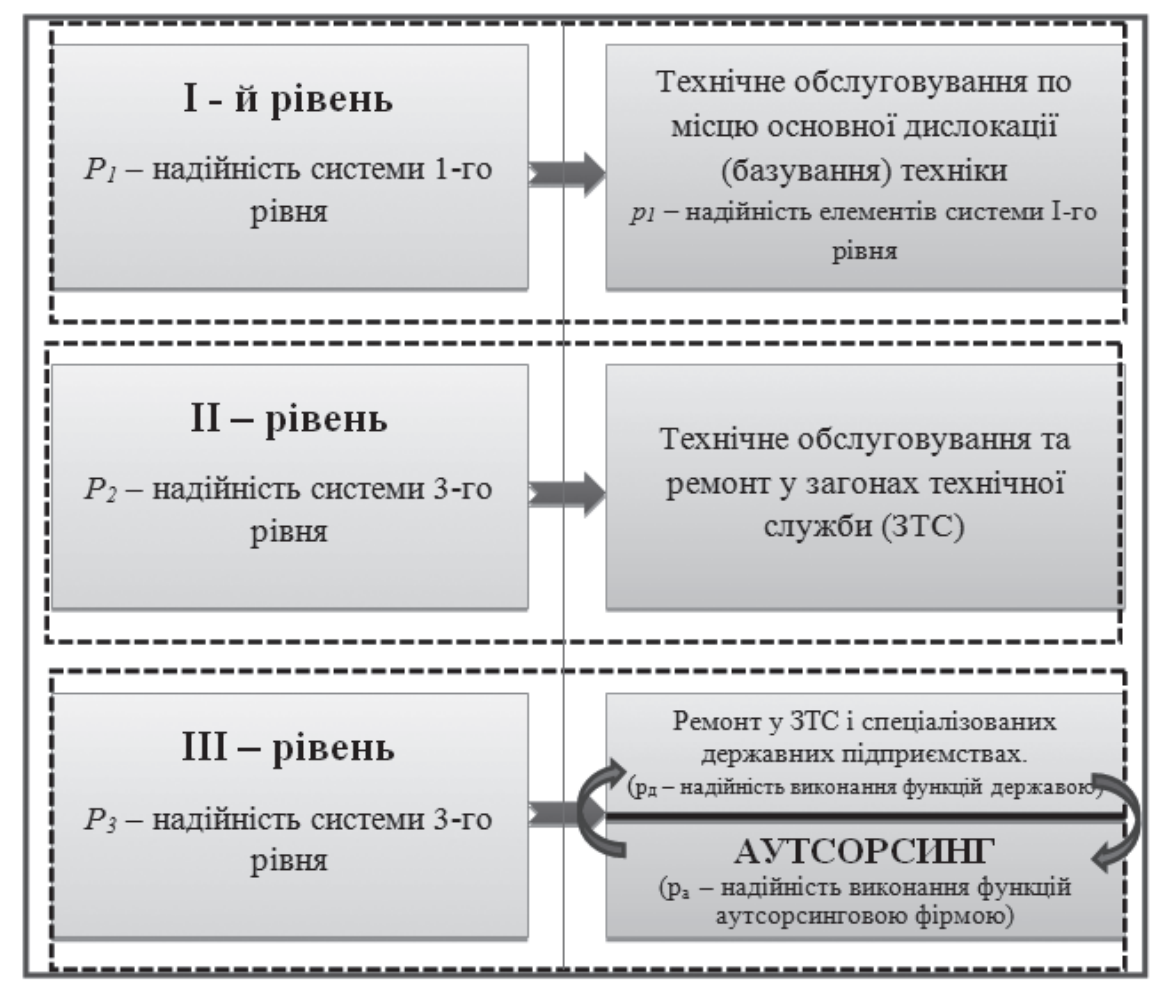

Рис. 2. Структурна схема трирівневої багатоканальної системи технічного обслуговування пожежно - рятувальної техніки із передачею функцій аутсорсингу на 3-му рівні системи. 
система має переваги у надійності функціонування над дворівневою. Також із позиції теорії ймовірності ми довели, що коли в такій системі на іiі третьому рівні буде здійснена $100 \%$ можливість аутсорсингової компанії у будь-який час перейняти на себе всі $100 \%$ функцій держави, і навпаки, рівень надійнос- ті третього рівня та всієї системи взагалі буде підвищено, що буде сприяти практично безвідмовному іiі функціонуванню. Ми пропонуємо прийняти дану трирівневу багатоканальну систему, як основу для реформування системи технічного обслуговування і ремонту пожежно-рятувальної техніки.

\section{БІБЛІОГРАФІЧНІ ПОСИЛАННЯ:}

1. Абдурагимов Г. И. Теория массового обслуживания в управлении пожарной охраной /Г. И. Абдурагимов, А. А. Таранцев. - М. : Акад. ГПС, 2000. - 101 с.

2. Башинський О. І. Обгрунтування методів управління ризиком у проекті реінжинірингу системи технічного обслуговування та ремонту пожежних автомобілів : автореф. дис... канд. техн. наук / Башинський О. I. - К., 1995.-25 с. 3. Безопасность жизнедеятельности : учеб. / Л. А. Михайлов, В. П. Соломин, А. Л. Михайлов, А. В. Старостенко [и др.]. - СПб. : Питер, 2006. - 302 с.

4. Безпека життєдіяльності (забезпечення соціальної, техногенної та природної безпеки) : навч. посіб. / В. В. Бєгун, I. М. Науменко. - К., 2004.-328 с.

5. Брушлинский Н. Н. Управление безопасностью сложных систем: методология, технологии, опыт / Н. Н. Брушлинский, Ю. М. Глуховенко [и др.] // Пробл. безоп. при чрезв. ситуациях. - 2002. - Вып. 6. C. $22-47$.

6. Буравлев А.И. Марковская модель восстановления военной техники вооружения и военной техники в новой системе технического обслуживания и ремонта / Журнал «Вооружение и экономика». - 2014.- Вып.1(26) - с. 37-52.

7. Визначення індивідуальних ризиків загибелі людей в Україні / I. О. Харченко, Т. М. Скоробагатько, Р. В. Климась, О. П. Якименко // Актуальні пробл. транспортної медицини. - 2007. - № 1. - С. 75 - 83.

8. Глобалізація: проблеми безпеки / С. П. Буравльов. - К. : Ін-т пробл. нац. безпеки, 2007. - 160 с.

9. Державне управління процесами забезпечення радіаційної безпеки в Україні : монографія / I. П. Кринична. - Д. : Пороги, 2009. - 304 с

10. Качанов С. А. Информационные технологии предупреждения и ликвидации чрезвычайных ситуаций : учеб. пособ. / С. А. Качанов, И. М. Тетерин, Н. Г. Топольский. - М. : Академия ГПС МЧС России, $2006.212 c$. 11. Клепко Є. А. Обеспечение пожарной безопасности городов и регионов на основе оценки и управления пожарными рисками : автореф. дис... канд. техн. наук : 05.13.10 / Клепко Е. А. ; Акад. гос. противопожар. службы МЧС России. - М., 2007. - 24 с.

12. Климась Р. В. Методи дослідження пожеж : метод. посіб. / Климась Р. В., Криса I. Я., Саріогло Р. [та ін.]. К. :ТОВ «Поліграфіст» «ТАТ», 2010. - 240 с.

13. Національна доповідь про стан техногенної та природної безпеки у 2012 році. - Режим доступу : http://www. mns.gov.ua.

14. Пожарная техника : учеб. / под ред. М. Д. Безбородько. - М. : Академия ГПС МЧС России, 2004. - 550 с.

15. Про затвердження Настанови з експлуатації транспортних засобів в органах та підрозділах ДСНС України : наказ ДСНС України № 432 від 27.06.2013 року. - Режим доступу : http://www.mns.gov.ua.

16. Сатин А. П. Метод замены пожарно-спасательной техники в системах управления материально-техническим обеспечением пожарно-спасательных формирований / А. П. Сатин // Технологии техносферной безопасности : интернет-журнал. - Вып. 3 (31). - 2011. - 8 c. - Режим доступа : http//ipb.mos.ru/ttb/2011-3.

17. Системный анализ и проблемы пожарной безопасности народного хозяйства / ред. Н. Н. Брушлинский. М. : Стройиздат, 1988. - 415 с.

18. Совершенствование организации и управления пожарной охраной / Н. Н. Брушлинский [и др.]. - М. : Стройиздат, 1986. - 149 с.

19. Соколов С. В. Разработка методов проектирования и совершенствования функционирования систем противопожарной защиты городов : автореф. дис... канд. тех. наук / Соколов С. В. ; МВД СССР, Высш. инженер. пожар.-техн. ш.. - М., 1989. - 25 с

20. Топольский Н. Г. Совершенствование материально-технического обеспечения МЧС России с использованием современных информационных технологий / Н. Г. Топольский, В. В. Симаков, А. П. Сатин // Матер. 15-й научн.-техн. конф. «Системы безопасности»- М. : Академия ГПС МЧС России, 2006. С. 67 - 69.

21. Удосконалення системи забезпечення пожежної безпеки в Україні: правові аспекти / В. Доманський // Право України. - 2002. - № 6. - С. 108 - 112.

22. Экономическая теория : учеб.-метод. комплекс : в 2 ч. / сост. Н. Н. Архипец. - ч. 1 «Экономическая теория». - Мн. : КИИ, 2005. - 201 c. 


\section{REFERENCES:}

1. Abduragimov, G. I., Tarancev, A. A., 2000. Teorija massovogo obsluzhivanija v upravlenii pozharnoj ohranoj [Queueing theory in management fire protection]. Moscow, 101 (in Russian).

2. Bashyns'kyj, O. I., 1995. Obg'runtuvannja metodiv upravlinnja ryzykom u proekti reinzhyniryngu systemy tehnichnogo obslugovuvannja ta remontu pozhezhnyh avtomobiliv [The rationale for methods of risk management in the project of reengineering of the system of technical maintenance and repair of fire engines]. Nauk. Kyiv, 25 (in Ukrainian).

3. Mihajlov, L. A., Solomin, V. P., Mihajlov,A. L., Starostenko, A. V., 2006. Bezopasnost' zhiznedejatel'nosti [Safety]. St. Petersburg, 302 (in Russian).

4. Bjegun, V. V., Naumenko, I. M., 2004. Bezpeka zhyttjedijal'nosti (zabezpechennja social'noi', tehnogennoi' ta pryrodnoi' bezpeky) [Health and safety (provision of social, technological and natural security)]. Kyiv, 328 (in Ukrainian).

5. Brushlinskij, N. N., 2002. Upravlenie bezopasnost'ju slozhnyh sistem: metodologija, tehnologii, opyt [Safety management of complex systems: methodology, technology, experience]. Probl. bezop. pri chrezv. situacijah 6, $22-47$ (in Russian).

6. Buravlev, A.I., 2014. Markovskaja model' vosstanovlenija voennoj tehniki vooruzhenija i voennoj tehniki v novoj sisteme tehnicheskogo obsluzhivanija i remonta [Markov model the restoration of military equipment weapons and military equipment in the new system of technical maintenance and repair]. Zhurnal «Vooruzhenie i jekonomika» 1(26), 37-52 (in Russian).

7. Harchenko, I.O., Skorobagat'ko, T. M., Klymas', R. V., Jakymenko, O. P., 2007. Vyznachennja indyvidual'nyh ryzykiv zagybeli ljudej v Ukrai'ni [The determination of individual risk of death of people in Ukraine]. Aktual'ni probl. transportnoi' medycyny $1,75-83$ (in Ukrainian).

8. Buravl'ov, Je. P., 2007. Globalizacija: problemy bezpeky [Globalization: security issues]. Kyiv, 160 (in Ukrainian).

9. Krynychna, I.P., 2009. Derzhavne upravlinnja procesamy zabezpechennja radiacijnoi’ bezpeky v Ukrai'ni [Public administration of radiation safety in Ukraine]. Dnipro, 304 (in Ukrainian).

10. Kachanov, S. A., 2006. Informacionnye tehnologii preduprezhdenija i likvidacii chrezvychajnyh situacij [Information technologies of prevention and liquidation of emergency situations]. Moscow, 212(in Russian).

11. Klepko, Y. A., 2007. Obespechenie pozharnoj bezopasnosti gorodov i regionov na osnove ocenki i upravlenija pozharnymi riskami [Fire safety of cities and regions based on the assessment and management of fire risk]. Moscow, 24 (in Russian).

12. Klymas', R. V., Krysa, I. Ja., Sarioglo, R., 2010. Metody doslidzhennja pozhezh [Research methods fires]. Kyiv, 240 (in Ukrainian).

13. Nacional'na dopovid' pro stan tehnogennoi' ta pryrodnoi' bezpeky u 2012 roci [National report on the state of technogenic and natural security in 2012]. Access: http://www.mns.gov.ua.

14. Bezborod'ko, M.D., 2004. Pozharnaja tehnika [Fire fighting equipment]. Moscow, 550 (in Russian).

15. Pro zatverdzhennja Nastanovy z ekspluatacii' transportnyh zasobiv v organah ta pidrozdilah DSNS Ukrai'ny : nakaz DSNS Ukrai'ny № 432 vid 27.06.2013 roku [About approval of the Instruction on operation of vehicles in bodies and divisions of gschs of Ukraine : the order of the SSES of Ukraine № 432 of 27.06.2013]. Access: http:// www.mns.gov.ua.

16. Satin, A. P., 2011. Metod zameny pozharno-spasatel'noj tehniki v sistemah upravlenija material'no-tehnicheskim obespecheniem pozharno-spasatel'nyh formirovanij [Method of replacement of firefighting and rescue equipment in the systems management logistical support fire-rescue units]. Tehnologii tehnosfernoj bezopasnosti : internet-zhurnal 3 (31), 8. Access: http//ipb.mos.ru/ttb/2011-3.

17. Brushlinskij, N.N., 1988. Sistemnyj analiz i problemy pozharnoj bezopasnosti narodnogo hozjajstva [System analysis and problems of fire safety of the national economy]. Moscow, 415 (in Russian).

18. Brushlinskij, N.N. [i dr.], 1986. Sovershenstvovanie organizacii i upravlenija pozharnoj ohranoj [Improving the organization and management of fire protection]. Moscow, 149 (in Russian).

19. Sokolov, S. V., 1989. Razrabotka metodov proektirovanija i sovershenstvovanija funkcionirovanija sistem protivopozharnoj zashhity gorodov [The development of design methods and to improve the functioning of the fire protection systems of cities]. Moscow, 25 (in Russian) .

20. Topol'skij, N. G., 2006. Sovershenstvovanie material'no-tehnicheskogo obespechenija MChS Rossii s ispol'zovaniem sovremennyh informacionnyh tehnologij [Improvement of material and technical support of EMERCOM of Russia with the use of modern information technologies]. «Sistemy bezopasnosti». Moscow, 67 - 69 (in Russian).

21. Domans'kyj, V., 2002. Udoskonalennja systemy zabezpechennja pozhezhnoi' bezpeky v Ukrai'ni: pravovi aspekty [Improving the system of fire safety in Ukraine: legal aspects]. Pravo Ukrai'ny 6, $108-112$ (in Russian). 22. Arhipec, N.N., 2005. Jekonomicheskaja teorija : ucheb.-metod. kompleks : v 2 ch. [Economic theory : textbook.-method. complex : in 2 parts]. «Jekonomicheskaja teorija». Minsk, 201 (in Russian). 